European journal of American studies

Special Issue: Wars and New Beginnings in American History

\begin{abstract}
A brief foreword to «Wars and New Beginnings in American History: An American National Rhetoric from the Early Republic to the Obama Presidency »

Jenel Virden
\end{abstract}

\title{
CpenEdition
}

Electronic version

URL: https://journals.openedition.org/ejas/9699

DOI: 10.4000/ejas.9699

ISSN: 1991-9336

Publisher

European Association for American Studies

Electronic reference

Jenel Virden, "A brief foreword to « Wars and New Beginnings in American History: An American National Rhetoric from the Early Republic to the Obama Presidency ", European journal of American studies [Online], 7-2 | 2012, document 1, Online since 29 March 2012, connection on 08 July 2021. URL: http:// journals.openedition.org/ejas/9699 ; DOI: https://doi.org/10.4000/ejas.9699

This text was automatically generated on 8 July 2021.

Creative Commons License 


\section{A brief foreword to « Wars and New Beginnings in American History: An American National Rhetoric from the Early Republic to the Obama Presidency »}

Jenel Virden

War has been a defining moment in the history of nations and no more so than in the United States. It gives the editors of EJAS great pleasure to present this excellent volume of essays focussed on the issue of American national rhetoric and American wars. This volume is comprised of essays that were presented at a workshop on "Wars and New Beginnings in American History", which took place in Dublin in 2010 at the biennial conference of the European Association for American Studies, or are invited contributions on the topic of American wars. While these essays explore the rhetorical theme of renewal and rejuvenation they also add new insights into wartime rhetoric. This collection is well-conceived and the essays hold together in a clear, logical way, in great part due to the splendid work of the co-editors Rob Kroes and Jean Kempf. This collection clearly demonstrates the quality of the work being done by European scholars and their colleagues on the history of the United States. The topic of war and America is, sadly, almost always current, which makes this volume particularly relevant and extremely topical. I am sure that the readers of EJAS will enjoy this latest volume of the journal. 


\section{AUTHOR}

JENEL VIRDEN

co-editor EJAS 